\title{
Hepatic Overexpression of GRP94 in a Rabbit Model of Parenteral Nutrition-Associated Liver Disease
}

\author{
Xueping Zhu, ${ }^{1}$ Xiaomin Zhang, ${ }^{1}$ Lingling Yu, ${ }^{1}$ Yumin Xu, ${ }^{1}$ Xing Feng, ${ }^{1}$ and Jian Wang ${ }^{2}$ \\ ${ }^{1}$ Department of Neonatology, Children's Hospital Affiliated to Soochow University, Suzhou, Jiangsu 215003, China \\ ${ }^{2}$ Department of Neonatology Surgery, Children's Hospital Affiliated to Soochow University, Suzhou, Jiangsu 215003, China
}

Correspondence should be addressed to Xing Feng; xing_feng66@hotmail.com and Jian Wang; wj196312@vip.163.com

Received 14 October 2014; Revised 1 March 2015; Accepted 11 March 2015

Academic Editor: Lana Bijelic

Copyright (C) 2015 Xueping Zhu et al. This is an open access article distributed under the Creative Commons Attribution License, which permits unrestricted use, distribution, and reproduction in any medium, provided the original work is properly cited.

Objective. To use a rabbit model of parenteral nutrition-associated liver disease (PNALD) to study changes of the endoplasmic reticulum stress (ERS) marker glucose regulatory protein 94 (GRP94) and determine its role in the pathogenesis of PNALD. Methods. A rabbit PNALD model total parenteral nutrition (TPN) group was established. A corresponding control group received breast-feeding for one week. Serum biochemical parameters were measured and liver histological examinations were performed. The level of GRP94 mRNA and protein were measured. Results. The results showed that the serum TBIL, DBIL, and $\gamma$-GT levels in the TPN group were significantly higher than those in the control group, while levels of serum ALB in TPN group were significantly lower than those in the control group. The immunohistochemistry results showed that the protein expression level of GRP94 in the liver of TPN group was significantly increased compared with the control group. The RT-PCR results showed that the level of GRP94 mRNA in the liver of the TPN group was significantly higher compared with the control group. Conclusions. The mRNA and protein levels of GRP94 in the TPN group were both significantly increased, indicating that ERS may be directly related to the occurrence and development of PNALD.

\section{Introduction}

Parenteral nutrition has brought about a revolutionary improvement in the care of neonates with growth failure due to intestinal dysfunction. Since the first reported case of long-term parenteral nutrition supplement in a newborn girl in the United States in the 1960s, there have been more than 30,000 patients whose survival has depended on parenteral nutrition [1]. However, long-term ( $>2$ weeks) parenteral nutrition is associated with a number of problems. Parenteral nutrition-related liver disease (PNALD) is one of the most serious complications of neonatal parenteral nutrition-associated liver disease, which usually presents with steatosis, cholestasis, and elevated aminotransferases. It has been reported [2] that about $30 \%-60 \%$ of children on long-term parenteral nutrition develop PNALD. Children born prematurely are more likely to suffer from total parenteral nutrition-associated cholestasis (PNAC) $[3,4]$ and even severe life-threatening cirrhosis. Despite the seriousness of the disease, the specific etiology and pathogenesis remains unclear.

Because hepatocytes have highly active protein synthetic activity and abundant endoplasmic reticulum, it is possible that endoplasmic reticulum stress response (ERS) may be involved. ERS has been shown to be involved in pathological changes of various liver diseases $[5,6]$. ERS has been implicated in the development of nonalcoholic steatohepatitis [7], alcoholic liver disease [8], ischemia/reperfusion liver injury [9], and cholestatic disease [10]. We hypothesized that ERS could also play an important role in development of PNALD. Glucose-regulated protein 94 (GRP94) is an important marker protein of ERS and a chaperone localized in the endoplasmic reticulum [11, 12]. As one of the known endoplasmic reticulum stress proteins, GRP94 has been shown to be important contributor to correct protein folding and processing, maintaining the stability of the endoplasmic reticulum under stress and generally protecting cells [12-14]. 
TABLE 1: Total parenteral nutrition solution formula (total liquid volume $240 \mathrm{~mL} \cdot \mathrm{kg}^{-1} \cdot \mathrm{d}^{-1}$ and total calories $210 \mathrm{kcal} \cdot \mathrm{kg}^{-1} \cdot \mathrm{d}^{-1}$ ).

\begin{tabular}{|c|c|c|c|}
\hline Ingredient & Volume (mL) & Calories (kcal) & Calories percentage $(\%)$ \\
\hline $20 \%$ medium/long-chain fat emulsion ${ }^{(1)}$ & 40.0 & 72.0 & 34.3 \\
\hline $11.4 \%$ compound amino acids & 80.0 & 36.4 & 17.3 \\
\hline $50 \%$ glucose & 36.0 & 72.0 & 48.4 \\
\hline $10 \%$ glucose & 74.0 & 29.6 & \\
\hline $10 \%$ sodium chloride & 4.0 & & \\
\hline $10 \%$ potassium chloride & 3.0 & & \\
\hline $10 \%$ calcium gluconate & 3.0 & & \\
\hline Water-soluble vitamins ${ }^{(2)}$ & $1 / 2$ ampoule & & \\
\hline Fat-soluble vitamins $^{(3)}$ & $1 / 2$ ampoule & & \\
\hline Total & 240.0 & 210.0 & \\
\hline
\end{tabular}

Thus, GRP94 could well be an indicator of ERS in liver disease. The aim of this study was to use a rabbit PNALD model to study the changes in expression the ERS marker protein GRP94 and determine its role in the pathogenesis of PNALD.

\section{Materials and Methods}

2.1. The PNALD Model and Experimental Groups. Sixteen 7-day-old breastfed New Zealand White rabbits, obtained from Wuxi Huishan Jiangnan Experimental Animal Center, were randomly divided into a total parenteral nutrition group (TPN group, $n=8$ ) and a control (breastfed) group $(n=8)$. The PNALD rabbit model was established as described previously $[15,16]$ with some modifications. Briefly, the TPN group received continuous total parenteral nutrition $240 \mathrm{~mL} / \mathrm{kg} \cdot \mathrm{d}$ for each rabbit, consisting of formula composition shown in Table 1 . Formula, $240 \mathrm{~mL}$, was introduced through a silastic catheter inserted in the right jugular vein. TPN group received $40 \mathrm{~mL}$ of a $20 \%$ medium- and long-chain fat emulsion $(72 \mathrm{kcal}, 34.3 \%$ of total calories), consisting of $2 \mathrm{~g}$ soy bean oil, $2 \mathrm{~g}$ medium chain triglyceride, and $0.24 \mathrm{~g}$ egg phospholipids; $80 \mathrm{~mL}$ of $11.4 \%$ pediatric compound amino acid injection-18AA-II (36.4 kcal, $17.3 \%$ of calories); $36 \mathrm{~mL}$ of $50 \%$ glucose $(72 \mathrm{kcal}$, $48.4 \%$ of calories); $74 \mathrm{~mL}$ of $10 \%$ glucose (29.6 kcal); $4 \mathrm{~mL}$ of $10 \% \mathrm{NaCl} ; 3 \mathrm{~mL}$ of $10 \% \mathrm{KCl} ; 3 \mathrm{~mL}$ of $10 \%$ calcium gluconate; half of a water soluble and fat-soluble vitamin ampoule originally containing $0.3 \mathrm{mg}$ vitamin $\mathrm{B} 1,0.36 \mathrm{mg}$ vitamin $\mathrm{B} 2$, $4 \mathrm{mg}$ nicotinamide, $0.4 \mathrm{mg}$ vitamin $\mathrm{B} 6,1.5 \mathrm{mg}$ pantothenic acid, $10 \mathrm{mg}$ vitamin C, $6 \mu \mathrm{g}$ biotin, $40 \mu \mathrm{g}$ folic acid, $0.5 \mu \mathrm{g}$ vitamin B12, $25 \mu \mathrm{g}$ (82.5 IU) vitamin A, $10.125 \mu \mathrm{g}$ (5 IU) vitamin $\mathrm{D}, 0.2275 \mathrm{mg}(0.25 \mathrm{IU})$ vitamin $\mathrm{E}$, and $3.75 \mu \mathrm{g}$ vitamin $\mathrm{Kl}$; and trace elements $\mathrm{CaCl}_{2} \cdot 2 \mathrm{H}_{2} \mathrm{O}, 39.25 \mathrm{mg}$; $\mathrm{MgCl}_{2} \cdot 6 \mathrm{H}_{2} \mathrm{O}, 15.21 \mathrm{mg} ; \mathrm{FeCl}_{3} \cdot 6 \mathrm{H}_{2} \mathrm{O}, 0.675 \mathrm{mg} ; \mathrm{ZnCl}_{2}$, $0.135 \mathrm{mg} ; \mathrm{MnCl}_{2} \cdot 4 \mathrm{H}_{2} \mathrm{O}, 0.395 \mathrm{mg} ; \mathrm{CuCl}_{2} \cdot 2 \mathrm{H}_{2} \mathrm{O}, 42.5 \mu \mathrm{g}$; $\mathrm{NaF}, 0.105 \mathrm{mg}$; and $\mathrm{KI}, 8.5 \mu \mathrm{g}$. Each $240 \mathrm{~mL}$ portion of TPN comprised $210 \mathrm{kcal}$ and the ratio of sugar to lipid was $1.4: 1$. The components in the mixture were purchased from Sino-Swed Pharmaceutical, China.
The control group received breast-feeding. Both groups were treated for one week and housed under conditions of constant temperature of $26-28^{\circ} \mathrm{C}$, relative humidity of $40-$ $60 \%$, and $12 \mathrm{~h}$ light and $12 \mathrm{~h}$ dark. The study protocol was approved by the Animal Care Committee of the Children's Hospital Affiliated to Soochow University.

2.2. Specimen Collection and Processing. All animals were anesthetized with $10 \%$ chloral hydrate by intraperitoneal injection and fixed on the dissecting table. The precordium was shaved and disinfected with iodine alcohol. The point of maximal impulse was identified and $2 \mathrm{~mL}$ blood was obtained by cardiac puncture and transferred to the anticoagulant tubes, centrifuged at $3500 \mathrm{rpm}$ serum, and stored at $-20^{\circ} \mathrm{C}$ freezer. The animals were killed by an overdose of anesthetic and the abdominal cavity was quickly opened. Liver tissue was excised and cleaned with normal saline. Some tissue was fixed in 10\% paraformaldehyde and 50-100 mg tissue samples were placed in tube and stored in liquid nitrogen until analyzed.

2.3. Blood Biochemical Tests. Serum total bilirubin (TBIL, $\mu \mathrm{M}$ ), bilirubin (DBIL, $\mu \mathrm{M}$ ), alanine aminotransferase (ALT, IU/L), aspartate aminotransferase (AST, IU/L), total protein (TP, g/L), albumin (ALB, g/L), $\gamma$-glutamyl peptidase $(\gamma$ GT, IU/L), alkaline phosphatase (ALP, IU/L), triglyceride (TG, mM), total cholesterol (TC, mM), and prealbumin (PA, mg/L) were measured by a Hitachi 7600 automatic biochemical analyzer (Japan).

2.4. Liver Pathology. Fresh liver tissue was fixed with $10 \%$ paraformaldehyde and dehydrated with serial different concentrations of alcohol. The dehydrated liver tissue was clear through xylene and embedded by paraffin. The paraffinembedded tissue blocks were cut into 5-micron thick slices, which were applied onto glass slides and dried in $45^{\circ} \mathrm{C}$ incubator. The glass slides were dewaxed and stained with hematoxylin and eosin ( $\mathrm{H}$ and $\mathrm{E})$. 
2.5. Measurement of GRP94 mRNA Levels in Liver Tissue by RT-PCR. Frozen liver tissue was thawed at room temperature and ground in DEPC-treated mortar. Total RNA was obtained using a Trizol extraction kit. RT-PCR was done using a Promega reverse transcription kit. Primers were designed using primer 5.0 software and synthesized by Shanghai Sangon Biological Engineering Company after a GenBank Blast search for homology. All operations were carried out according to the kit instructions. Rabbit GAPDH was selected as internal reference whose expected fragment size was $497 \mathrm{bp}$. The primers were forward: $5^{\prime}$-GTTTGTGATGGGCGTGAA-3' ${ }^{\prime}$; reverse: $5^{\prime}$-CGAAGGTAGAGGAGTGGGTG-3'. GRP94 fragment size was $583 \mathrm{bp}$ and primers were forward: $5^{\prime}$-AGGAAACACTCTGGGACG3'; reverse: $5^{\prime}$-ATTCAGGTACTTAGGCATC-3'. RT-PCR products were observed on a $1.5 \%$ agarose gel electrophoresis. Semiquantitative analysis was made in Bio2239 gel imager (Bio-Print Company).

\subsection{GRP94 Protein Levels in Liver Tissue as Determined} by Immunohistochemistry. Immunohistochemical analyses were conducted using a streptomyces avidin-peroxidase link method. All slides were pretreated with polylysine (Boster Biological Engineering Co., Ltd.). Cells with brownish yellow granules in the cytoplasm were considered to be positive. Liver tissue slices in glass slides were observed by light microscopy after immunohistochemical staining according to the manufacturer's instructions (Suzhou En Maike Biotechnology Co., Ltd.). Three nonoverlapping fields of view at high magnification $(\times 400)$ were randomly selected from each slide for gray degree scanning using Image-Pro-Plus image analysis software system. The average gray level of each group was calculated to reflect the positive intensity of GRP94.

2.7. Statistical Analysis. Statistical analysis was made using SPSS17.0 statistical software. Quantitative data were described as mean \pm standard deviation. Comparisons between two groups of quantitative variables were performed using Student's $t$-test. $P$ values $<0.05$ were considered to indicate statistical significance.

\section{Results}

3.1. Biochemical Parameters in the TPN and Control Groups. There were statistically significant differences in serum levels of TBIL $(t=41.59, P<0.01)$, DBIL $(t=33.38, P<0.01)$, $\gamma$-GT $(t=39.07, P<0.01)$, and ALB $(t=-12.36, P<0.01)$ between the two groups. However, there were no statistically significant differences in serum TP, ALT, AST, ALP, TG, TC, or PA $(P>0.05)$. Compared to the control group, serum TBIL, DBIL, and $\gamma$-GT levels in the TPN group were significantly higher $(P<0.01)$, while ALB was significantly lower $(P<0.01)$. These results are shown in Table 2 and Figure 1.

3.2. Liver Histology in the TPN and Control Groups. The liver tissue of the control group showed morphological normal hepatocytes, with no bile duct abnormalities, inflammatory

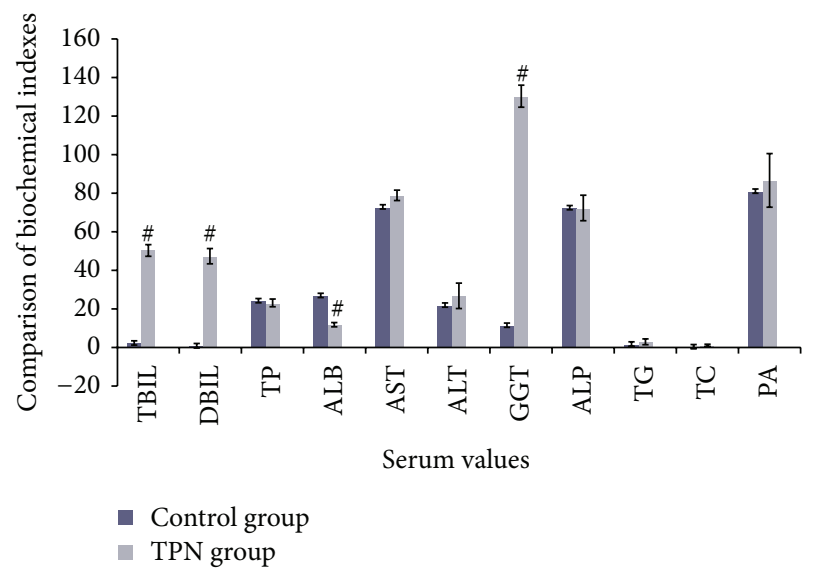

FIgURE 1: A comparison of serum biochemical data from the TPN and control groups. Note: each value is the mean \pm SD of assays using 8 independent samples. Compared with the control group, ${ }^{\#} P<0.01$. TBIL: total bilirubin, DBIL: direct bilirubin, TP: total protein, ALB: albumin, AST: aspartate aminotransferase, ALT: alanine aminotransferase, r-GT: r-glutamyl GGT, ALP: alkaline phosphatase, TG: triglycerides, TC: total cholesterol, and PA: prealbumin.

cell infiltration, or hepatocyte degeneration and necrosis, as shown in Figures 2(a) and 2(b). In contrast, in liver tissue of the TPN, there were inflammatory cell infiltration, diffuse steatosis, and liver cell cord structural disorder. However, there were no bile duct dilatation or epithelial hyperplasia, no significant cholestasis, and no visible fibrosis group with lobular structure, as shown in Figures 2(c) and 2(d).

3.3. Levels of Liver GRP94 Protein in the TPN and Control Groups. Immunohistochemistry showed that GRP94 protein expression gray values in the TPN group and the control group were $133.838 \pm 13.66,78.138 \pm 8.169$, respectively. GRP94 protein levels in the TPN group were significantly higher than those in the controls $(P<0.01)$ as shown in Figures 3(a), 3(b), and 3(c) and Table 3.

3.4. Liver GRP94 mRNA Levels in the TPN and Control Groups. RT-PCR in the liver tissue showed that the GRP94 mRNA expression gray values in the TPN group and the control group were $1.217 \pm 0.112$ and $0.614 \pm 0.034$, respectively. GRP94 mRNA expression gray values in the TPN group were significantly higher than those of controls $(P<0.01)$ as shown in Table 4 and Figure 4.

\section{Discussion}

Parenteral nutrition has offered powerful nutritional support for critically ill infants including those who fail to get enteral nutrition. But at the same time, there are also negative effects during long-term parenteral nutrition, which are mainly PNALD occurrence [17]. However, the etiology and pathogenesis of PNALD are poorly understood [18-21]. Hepatocytes perform a myriad of metabolic functions and thus are enriched in both smooth and rough ER. Recently, 


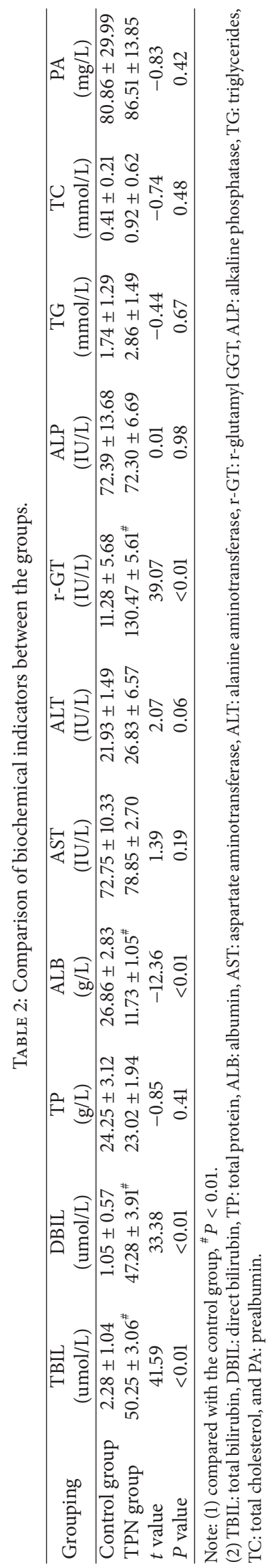




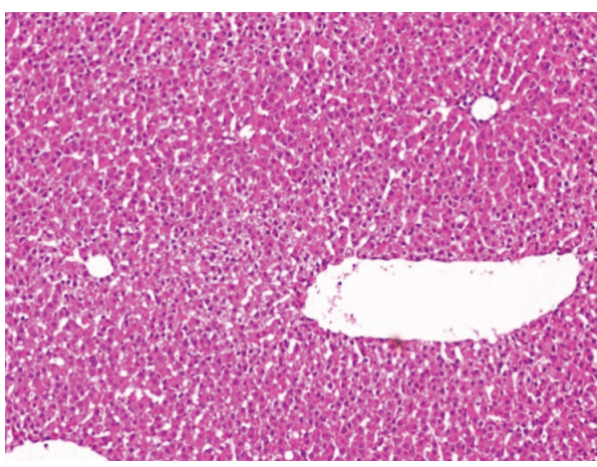

(a)

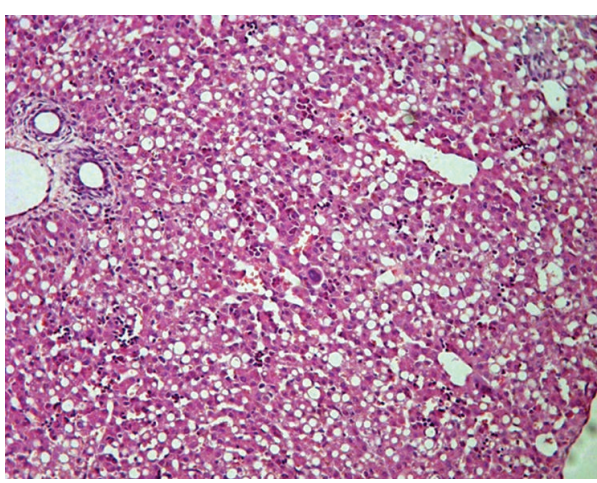

(c)

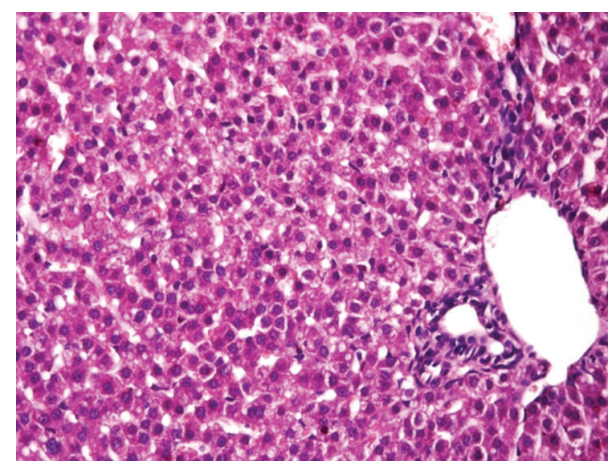

(b)

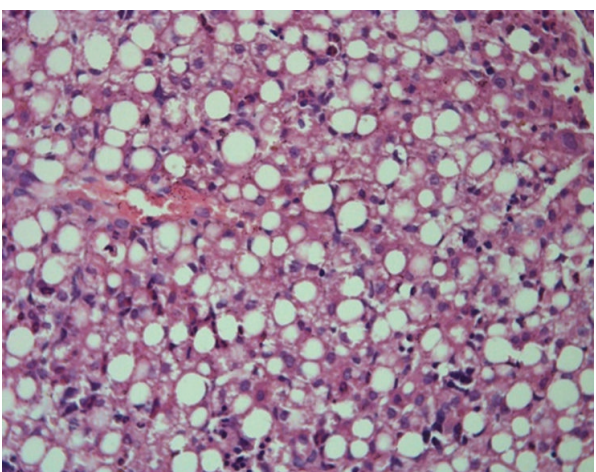

(d)

FIGURE 2: Representative sections of livers from the TPN and control groups obtained on $\mathrm{d} 7$ and stained with H and E. Note: (a) control group, 200x; (b) control group, 400x; (c) TPN group, 200x; and (d) TPN group, 400x.

TABLE 3: GRP94 protein expression gray values in liver tissues $( \pm s)$.

\begin{tabular}{lc}
\hline Groups & GRP94 protein expression gray values $(\bar{x} \pm s)$ \\
\hline Control group $(n=8)$ & $78.138 \pm 8.169$ \\
TPN group $(n=6)$ & $133.838 \pm 13.664^{\#}$ \\
$t$ value & -9.546 \\
$P$ value & $<0.01$ \\
\hline
\end{tabular}

Note: compared with the control group, ${ }^{\#} P<0.01$.

TABLE 4: Comparison of liver tissue GRP94 mRNA level gray values $(\bar{x} \pm s)$.

\begin{tabular}{lc}
\hline Groups & GRP94 mRNA \\
\hline Control group $(n=8)$ & $0.614 \pm 0.034$ \\
TPN group $(n=6)$ & $1.217 \pm 0.112^{\#}$ \\
$t$ value & -14.427 \\
$P$ value & $<0.01$ \\
\hline
\end{tabular}

Note: compared with the control group, ${ }^{\#} P<0.01$.

ERS response has been observed in a variety of liver diseases and ERS response accompanies nearly all forms of acute and chronic liver disease [5-10]. Some of these observations offer mechanistic insights and present potential therapeutic targets. However, it is not known whether ERS response also plays an important role in PNALD. These associations of ERS response and other liver diseases also may indicate that a new hypothesis is required to test the role of the ERS in PNALD. To test the hypothesis, the expression changes of GRP94, which is one of ERS marker proteins, were analyzed in a rabbit PNALD model.

ERS has been shown to be involved in preventing protein misfolding and unfolding, thus contributing to the maintenance of cell survival and normal function [22]. However, ERS of long duration can induce apoptosis [22]. Correct protein folding within the endoplasmic reticulum requires the assistance of chaperone proteins, such as Bip/GRP78 and GRP94, and folding enzymes [23]. Under normal conditions, the endoplasmic reticulum chaperones Bip/GRP78, GRP94 and Ire1, ATF6, and PERK combine to form a stable complex and stays in the endoplasmic reticulum lumen. When protein unfolding occurs, a large number of these unfolded or misfolded proteins accumulate resulting in dissociation of Ire1, ATF6, PERK, and BIP [23]. Excessively long or strong ERS can increase the levels of ERS-related protein GRP94 [24]. It is widely accepted that GRP94 is an ERS marker [25]. Therefore, GRP94 was selected for detecting the occurrence of ERS in PNALD.

In the current study, after one week of intravenous nutrition in 7-day-old rabbits, serum TBIL, DBIL, and $\gamma$ GT in the TPN group were significantly higher $(P<0.01)$, while ALB was significantly lower $(P<0.01)$ than that in control group. Liver pathology showed inflammatory cell infiltration, diffuse steatosis, and liver cell cord structural disorder in the TPN group, while these changes were not 


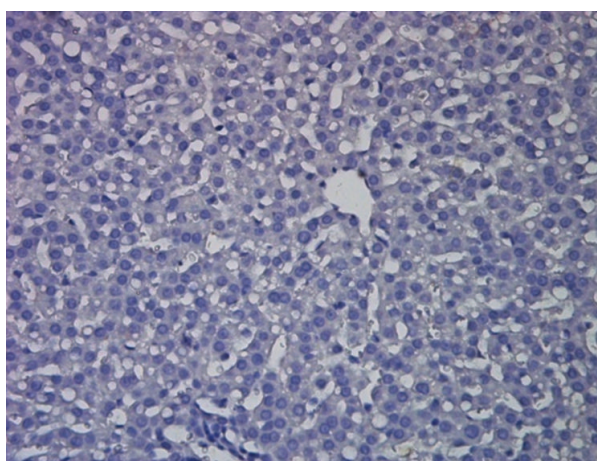

(a)

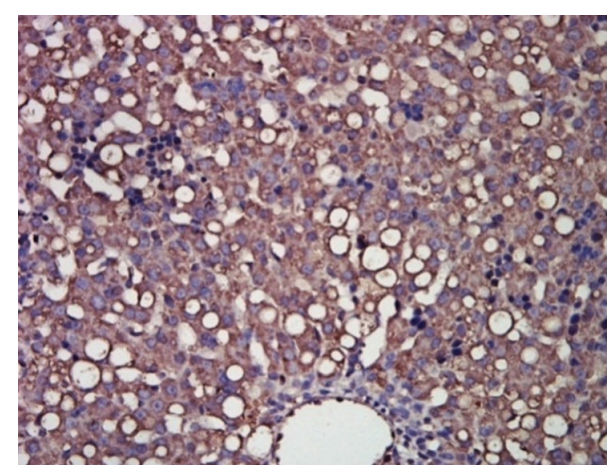

(b)

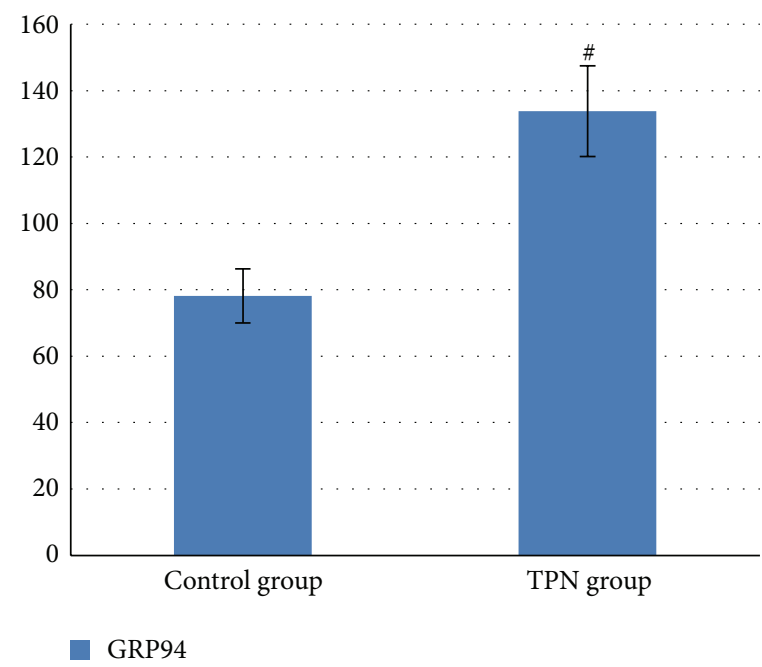

(c)

FIGURE 3: Representative immunohistochemical staining of GRP94 protein in liver tissue from the TPN and control groups. Note: (a) control group, 400x; (b) TPN group, 400x; and (c) a GRP94 protein expression gray value histogram of liver tissue from the two groups. Compared with the control group, ${ }^{\#} P<0.01$.

observed in the control group. Liver damage occurred after 1 week of TPN that was consistent with previous research results $[16,17]$. The immunohistochemistry results showed that the protein expression level of GRP94 in the liver of TPN group was significantly increased compared with the control group $(133.838 \pm 13.664$ versus $78.138 \pm 8.169)(P<$ $0.01)$. The RT-PCR results showed that the expression level of GRP94 mRNA in the liver of the TPN group was significantly increased compared with the control group $(1.217 \pm 0.113$ versus $0.614 \pm 0.034)(P<0.01)$. Therefore, the mRNA and protein expression of GRP94 in the TPN group were both significantly increased, which indicated that ERS may be directly related to the occurrence and development of PNALD.

In the PNALD model, $\gamma$-GT activity, which is mainly attributed to the hepatobiliary system [26], has been reported to be significantly increased. While TBIL was also significantly increased, the largest contribution to the elevated TBIL was DBIL but not IBIL. Hyperbilirubinemia with mainly DBIL elevation often suggests bile duct injury or obstruction. An elevation of GGT which has been reported to be closely related to hepatic steatosis [27-29] was also observed in liver pathology results of the current study. With severe liver damage, synthesis, intracellular transport, and release of ALB can be affected resulting in decreased serum ALB [30]. Therefore, long-term parenteral nutrition may cause inflammatory cell infiltration, diffuse steatosis, and liver cell cord structural disorder in liver. This liver pathology change may be accompanied with elevated serum DBIL and $\gamma$ GT and decreased serum ALB. Therefore, we speculate that increases in TBIL, DBIL, and $\gamma$-GT and the reduction of ALB levels may be early indicators of the development of PNALD.

There are limitations to this study. The number of experiments was small, and the experimental TPN application period was not long enough to observe cholestatic changes. Future experiments should be done for longer durations of treatment to observe the relations of relevant biochemical and the occurrence and development of PNALD. There is, however, a problem related with the specificity of these results for parenteral nutrition therapy since controls for the stress were not included (separation from the mother, anesthesia, catheter inserted in the right jugular vein, infusion, etc.). This limitation is likely not significant based on our previous report that soybean oil parenteral nutrition was associated with significant liver dysfunction, as indicated by higher 


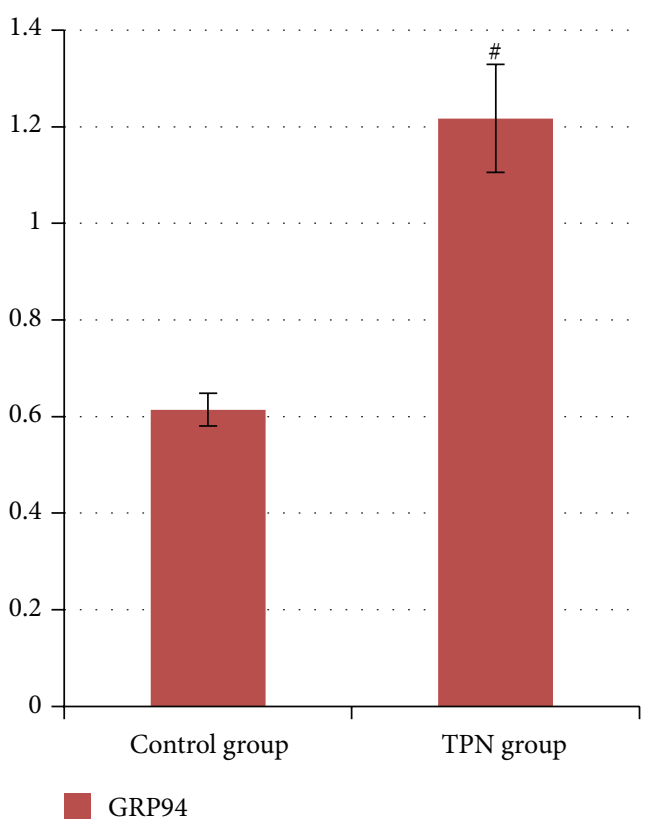

(a)

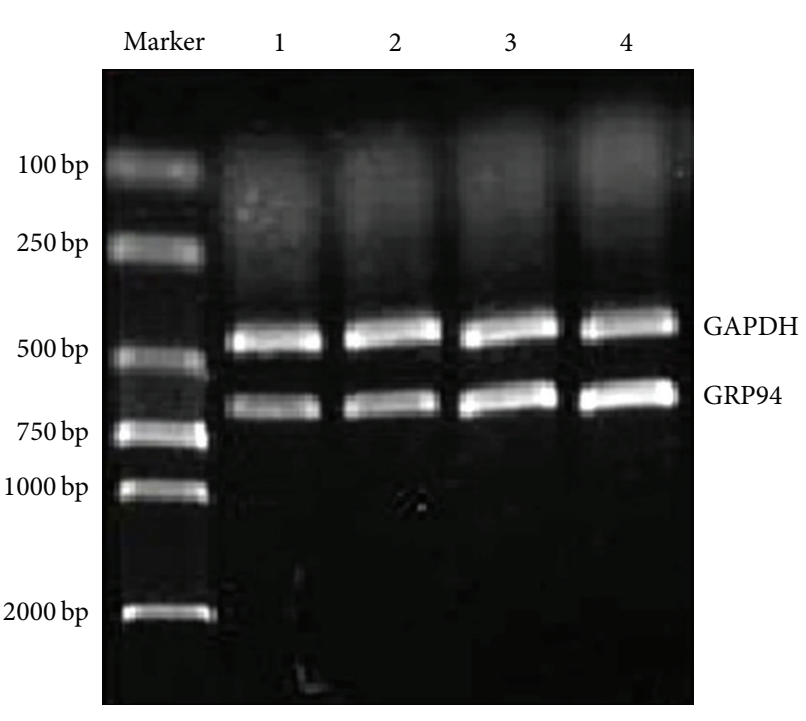

(b)

FIgURE 4: (a) A gray value histogram of GRP94 mRNA levels in liver tissue from the two groups. Compared with the control group, ${ }^{\#} P<0.01$. The bands were quantified as the relative integrated optical density (IOD) values of the ratio of GRP94/GAPDH for two groups, mean \pm SD, $n=8$. (b) Liver tissue GRP94 mRNA amplified by RT-PCR and analyzed by electrophoresis. Lanes: marker, DNA marker; 1 and 2 , control group; 3 and 4, TPN group.

serum total bilirubin, direct bilirubin, and $\gamma$-GT and lower serum albumin levels compared to control. These effects were not observed in the fish oil fat emulsion group (TPNFO), which was similar to the control. Moreover, histological examination of liver tissues revealed hepatic damage in the soybean fat emulsion group (TPN-soy) not seen in the TPNFO, including inflammatory cell infiltration, diffuse hepatic steatosis, and disrupted hepatic cord structure [31].

\section{Conclusion}

In conclusion, the current study showed that the mRNA and protein levels of GRP94 in the TPN group were both significantly increased compared with those in the control group. The differences were statistically significant $(P<$ $0.05)$. These results indicate that ERS occurred in the TPN group and may be involved in the development of PNALD. This information may provide an important novel basis for the detection and prevention of PNALD.

\section{Conflict of Interests}

The authors declare that there is no conflict of interests regarding the publication of this paper.

\section{Authors' Contribution}

Xueping Zhu and Xiaomin Zhang contributed equally to this work.

\section{Acknowledgments}

This research was supported by grants from the Suzhou Science and Technology Development Project (SYS201136 and SYS201440) and the Jiangsu Province Health Department surface scientific research project (H201316), Natural Science Foundation Project of Jiangsu Province (no. BK20141183), 135 Project of Department of Health of Jiangsu Province (no. RC2007076), and the Research Project of the Suzhou Key Laboratory of Children's Developmental Brain Injury Prevention and Care (no. SZS201108). The authors gratefully acknowledge all members of the laboratory for sharing reagents and advice. The authors thank the pathologist for reviewing the histology slides.

\section{References}

[1] S. J. Rangel, C. M. Calkins, R. A. Cowles et al., "Parenteral nutrition-associated cholestasis: an American pediatric surgical association outcomes and clinical trials committee systematic review," Journal of Pediatric Surgery, vol. 47, no. 1, pp. 225-240, 2012.

[2] K. M. Gura, S. Lee, C. Valim et al., "Safety and efficacy of a fishoil based fat emulsion in the treatment of parenteral nutrition associated liver disease," Pediatrics, vol. 121, no. 3, pp. e678e686, 2008

[3] C. J. Klein, T. G. Havranek, M. E. Revenis, Z. Hassanali, and L. M. Scavo, "Plasma fatty acids in premature infants with hyperbilirubinemia: before-and-after nutrition support with fish oil emulsion," Nutrition in Clinical Practice, vol. 28, no. 1, pp. 87-94, 2013. 
[4] A. Kubota, N. Mochizuki, J. Shiraishi et al., "Parenteralnutrition-associated liver disease after intestinal perforation in extremely low-birthweight infants: consequent lethal portal hypertension," Pediatrics International, vol. 55, no. 1, pp. 39-43, 2013.

[5] L. Dara, C. Ji, and N. Kaplowitz, "The contribution of endoplasmic reticulum stress to liver diseases," Hepatology, vol. 53, no. 5, pp. 1752-1763, 2011.

[6] H. Malhi and R. J. Kaufman, "Endoplasmic reticulum stress in liver disease," Journal of Hepatology, vol. 54, no. 4, pp. 795-809, 2011.

[7] M. J. Pagliassotti, "Endoplasmic reticulum stress in nonalcoholic fatty liver disease," Annual Review of Nutrition, vol. 32, pp. 17-33, 2012.

[8] A. Fernandez, N. Matias, R. Fucho et al., "ASMase is required for chronic alcohol induced hepatic endoplasmic reticulum stress and mitochondrial cholesterol loading," Journal of Hepatology, vol. 59, no. 4, pp. 805-813, 2013.

[9] C. D. Anderson, G. Upadhya, K. D. Conzen et al., "Endoplasmic reticulum stress is a mediator of posttransplant injury in severely steatotic liver allografts," Liver Transplantation, vol. 17, no. 2, pp. 189-200, 2011.

[10] B.-H. Dai, L. Geng, Y. Wang et al., "MicroRNA-199a-5p protects hepatocytes from bile acid-induced sustained endoplasmic reticulum stress," Cell Death \& Disease, vol. 4, no. 4, article e604, 2013.

[11] D. Eletto, D. Dersh, and Y. Argon, "GRP94 in ER quality control and stress responses," Seminars in Cell and Developmental Biology, vol. 21, no. 5, pp. 479-485, 2010.

[12] M. Marzec, D. Eletto, and Y. Argon, "GRP94: an HSP90-like protein specialized for protein folding and quality control in the endoplasmic reticulum," Biochimica et Biophysica ActaMolecular Cell Research, vol. 1823, no. 3, pp. 774-787, 2012.

[13] K. Araki and K. Nagata, "Protein folding and quality control in the ER," Cold Spring Harbor Perspectives in Biology, vol. 4, no. 8, Article ID a015438, 2012.

[14] D. Morito and K. Nagata, "ER stress proteins in autoimmune and inflammatory diseases," Frontiers in Immunology, vol. 48, no. 3, pp. 1-8, 2012.

[15] S. Hata, S. Kamata, R. Nezu, Y. Takagi, and A. Okada, "A newborn rabbit model for total parenteral nutrition: effects of nutritional components on cholestasis," Journal of Parenteral and Enteral Nutrition, vol. 13, no. 3, pp. 265-271, 1989.

[16] J. Wu, Y. F. Xu, and W. Cai, "The establishment of total parenteral nutrition-related cholestasis infant rabbits model," Clinical Pediatrics, vol. 22, pp. 107-109, 2004.

[17] E. M. Tillman, "Review and clinical update on parenteral nutrition-associated liver disease," Nutrition in Clinical Practice, vol. 28, no. 1, pp. 30-39, 2013.

[18] S. S. Kaufman, G. E. Gondolesi, and T. M. Fishbein, "Parenteral nutrition associated liver disease," Seminars in Neonatology, vol. 8, no. 5, pp. 375-381, 2003.

[19] P. Nandivada, E. Cowan, S. J. Carlson, M. Chang, K. M. Gura, and M. Puder, "Mechanisms for the effects of fish oil lipid emulsions in the management of parenteral nutrition-associated liver disease," Prostaglandins Leukotrienes and Essential Fatty Acids, vol. 89, no. 4, pp. 153-158, 2013.

[20] M. P. Cober and D. H. Teitelbaum, "Prevention of parenteral nutrition-associated liver disease: lipid minimization," Current Opinion in Organ Transplantation, vol. 15, no. 3, pp. 330-333, 2010.
[21] D. A. Kelly, "Intestinal failure-associated liver disease: what do we know today?" Gastroenterology, vol. 130, no. 2, supplement 1, pp. S70-S77, 2006.

[22] E. Szczesna-Skorupa, C.-D. Chen, H. Liu, and B. Kemper, "Gene expression changes associated with the endoplasmic reticulum stress response induced by microsomal cytochrome p450 overproduction," The Journal of Biological Chemistry, vol. 279, no. 14, pp. 13953-13961, 2004.

[23] D. Qing and Z. Zhen, "The role of endoplasmic reticulum stress in liver disease," International Journal of Internal Medicine, vol. 36, no. 11, pp. 665-671, 2009.

[24] Z. Q. Li, A. R. Li, and C. S. Tang, "The molecular mechanism study of endoplasmic reticulum stress response," Chinese Journal of Biochemistry and Molecular Biology, vol. 20, no. 3, pp. 283288, 2004.

[25] Y. Ma and L. M. Hendershot, "ER chaperone functions during normal and stress conditions," Journal of Chemical Neuroanatomy, vol. 28, no. 1-2, pp. 51-65, 2004.

[26] J. B. Whitfield, "Gamma glutamyl transferase," Critical Reviews in Clinical Laboratory Sciences, vol. 38, no. 4, pp. 263-355, 2001.

[27] L. P. Breitling, V. Arndt, C. Drath, and H. Brenner, "Liver enzymes: interaction analysis of smoking with alcohol consumption or BMI, comparing AST and ALT to $\gamma$-GT," PLoS ONE, vol. 6, no. 11, Article ID e27951, 2011.

[28] L. P. Breitling, H. Claessen, C. Drath, V. Arndt, and H. Brenner, "Gamma-glutamyltransferase, general and cause-specific mortality in 19,000 construction workers followed over 20 years," Journal of Hepatology, vol. 55, no. 3, pp. 594-601, 2011.

[29] E. G. Giannini, R. Testa, and V. Savarino, "Liver enzyme alteration: a guide for clinicians," Canadian Medical Association Journal, vol. 172, no. 3, pp. 367-379, 2005.

[30] Z. Q. Sun, Y. L. Mao, X. Q. Chen, J. X. Guo, L. M. Liu, and Y. L. Cong, "Formulation and application of diagnostic models based on clinical biochemical assays in diagnosis of chronic hepatitis and liver cirrhosis associated with viral hepatitis," Chinese Journal of Experimental and Clinical Virology, vol. 21, no. 3, pp. 276-278, 2007.

[31] X. Zhu, Z. Xiao, X. Chen et al., "Parenteral nutrition-associated liver injury and increased GRP94 expression prevented by $\omega$ 3 fish oil-based lipid emulsion supplementation," Journal of Pediatric Gastroenterology and Nutrition, vol. 59, no. 6, pp. 708713, 2014. 


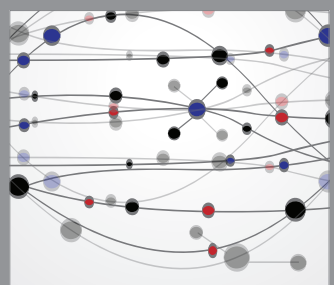

The Scientific World Journal
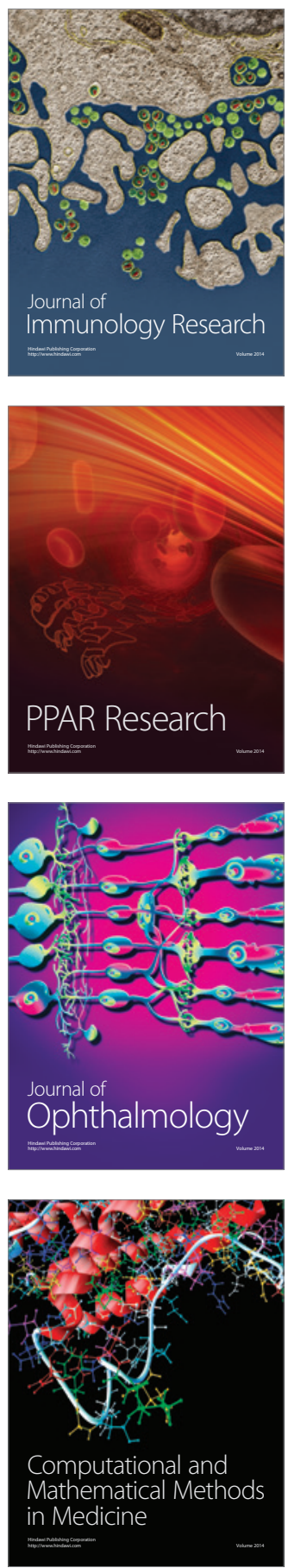

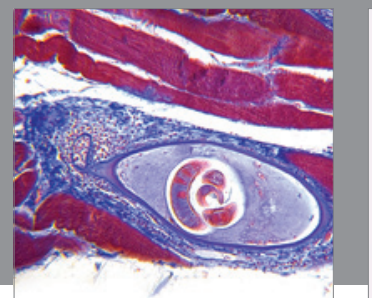

Gastroenterology

Research and Practice
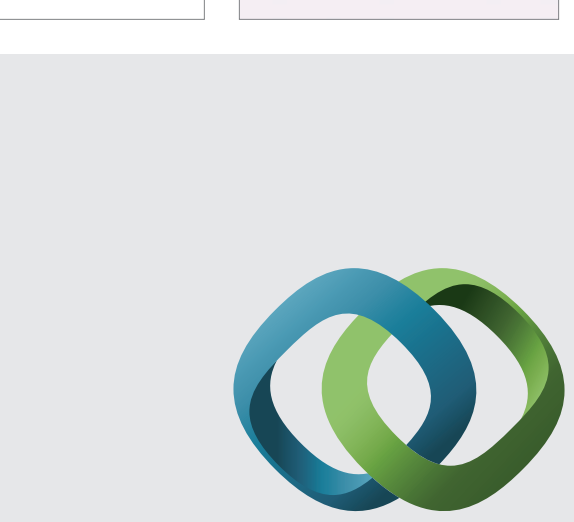

\section{Hindawi}

Submit your manuscripts at

http://www.hindawi.com
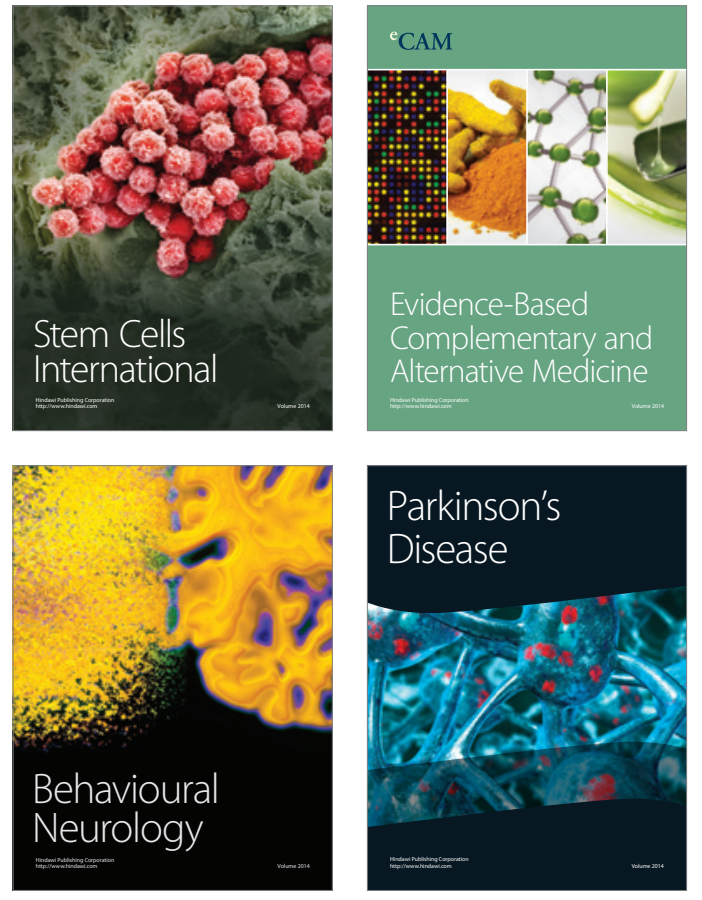
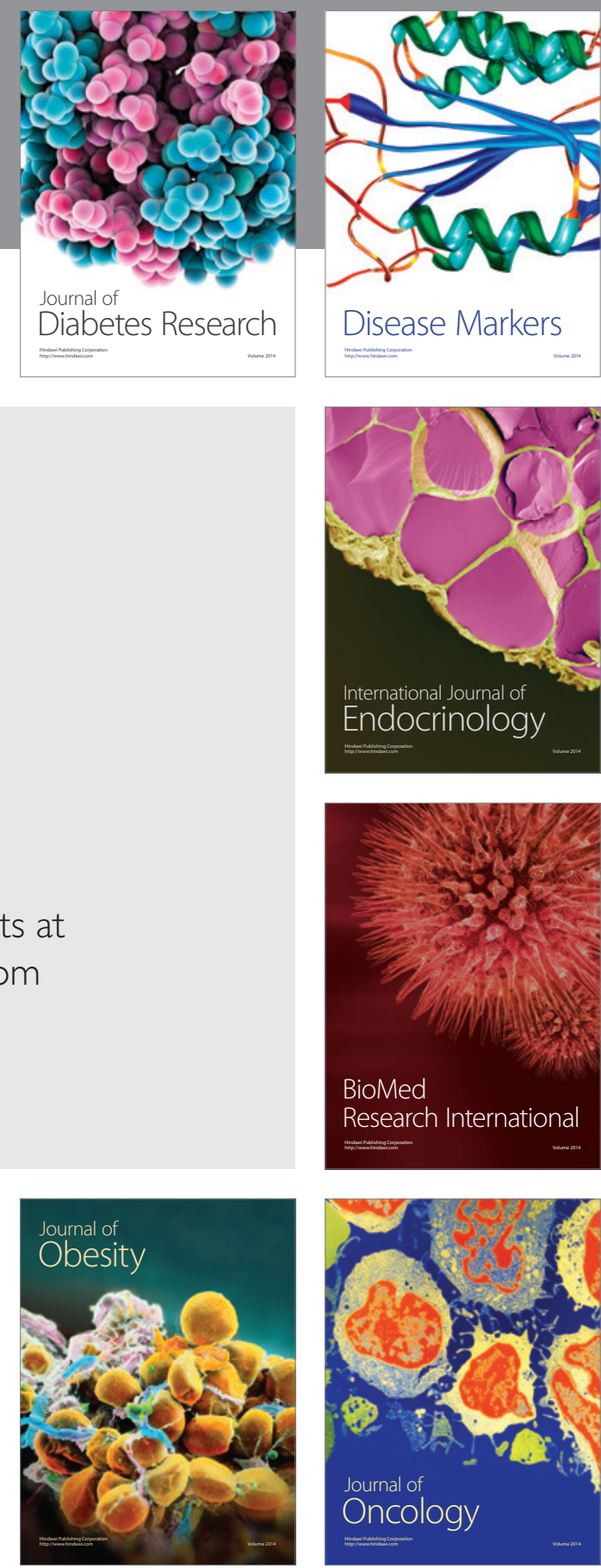

Disease Markers
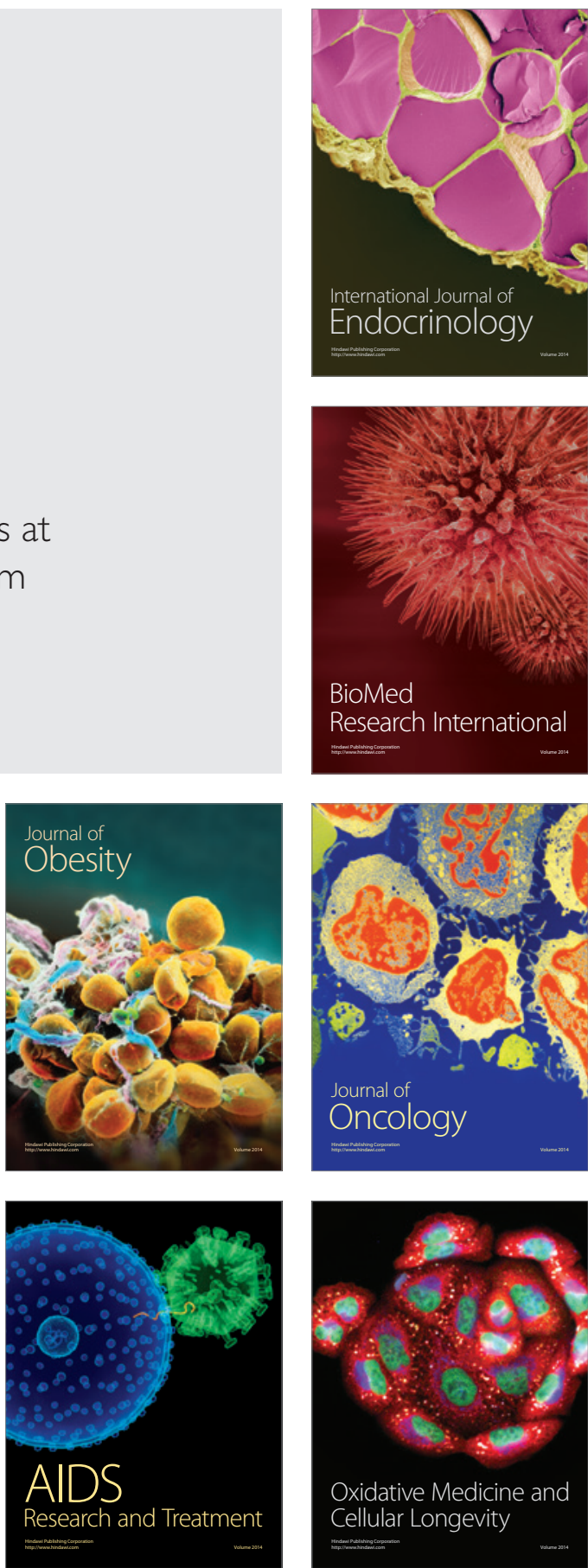